\title{
EDITORIAL
}

\section{Preflight medical screening of patients}

\author{
R. Naeije
}

Travel by commercial jet aircraft is a popular, expeditious, safe and generally affordable mode of transportation. Millions of passengers fly all over the world every year. A proportion of them are disabled, or have experienced recent injury or illness. Despite the comfort and convenience of modern commercial aircraft, there are environmental factors that may affect some persons, particularly those with limited physiological reserve. By far the most important one is reduced barometric pressure $(P \mathrm{~B})$, which may expose patients with altered pulmonary gas exchange to a poorly tolerated hypoxic stress.

Altitude is associated with a decrease in $P \mathrm{~B}$. The cruising altitude of most commercial airliners is 9,000-12,000 $\mathrm{m}$, which corresponds to a $P \mathrm{~B}$ decrease from the sea-level $101 \mathrm{kPa}(760 \mathrm{mmHg})$ to $30.7-19.3 \mathrm{kPa}(231-145 \mathrm{mmHg})$. The inspired partial pressure of oxygen $\left(P \mathrm{I}, \mathrm{O}_{2}\right)$ at $9,000 \mathrm{~m}$ can be calculated from the equation:

$$
\begin{gathered}
P_{\mathrm{I}, \mathrm{O}_{2}=} F_{\mathrm{I}, \mathrm{O}_{2}}\left(P \mathrm{~B}-P_{\text {air } \left., \mathrm{H}_{2} \mathrm{O}\left(37^{\circ} \mathrm{C}\right)\right)=} .1 \mathrm{kPa}(39 \mathrm{mmHg}),\right.
\end{gathered}
$$

where $F \mathrm{I}, \mathrm{O}_{2}$ is the inspiratory oxygen fraction $(0.21$, which does not change with altitude) and $P$ air, $\mathrm{H}_{2} \mathrm{O}\left(37^{\circ} \mathrm{C}\right)$ the partial pressure of water at $37^{\circ} \mathrm{C}(6.3 \mathrm{kPa}(47 \mathrm{mmHg}))$. This is probably the extreme $P \mathrm{I}, \mathrm{O}_{2}$ compatible with human life, tolerable only for some highly trained mountaineers climbing Mount Everest $(8,840 \mathrm{~m})$ after several weeks' acclimatization [1]. Acutely, exposure to an altitude of 9,000 m is associated with loss of consciousness in $<1 \mathrm{~min}$ [1].

Hypobaric hypoxia, in aeroplanes, is prevented either by increasing the $F \mathrm{I}_{1} \mathrm{O}_{2}$, with an $\sim 1 \%$ increase corresponding to a decrease in altitude of $300 \mathrm{~m}$, or by increasing cabin pressure. Aviation regulations specify that flights in nonpressurized aircraft at an altitude of $>3,000 \mathrm{~m}$ require supplemental oxygen delivered by a face mask, and that aircraft cruising at altitudes of $>6,000 \mathrm{~m}$ must be pressurized [2]. It is technically difficult, and costly, to pressurize cabins equivalent to sea-level altitudes. The cabin pressure used is a compromise between the need to avoid any untoward physiological effect of hypobaric hypoxia and technical and economic imperatives [3]. The American Federal Aeronautical Regulations specify that the cabin pressure must not be lower than an equivalent altitude of $2,434 \mathrm{~m}$, with tolerance to a pressure equivalent to a cabin altitude of up to $3,000 \mathrm{~m}$ in case of a technical problem [2]. Supplemental oxygen is mandatory at pres-

Correspondence: R Naeije, Dept of Physiology, Faculty of Medicine, ULB, Erasme Campus CP 604, Lennik road, 808, B-1070 Brussels, Belgium. Fax: 3225554124. sures equivalent to higher cabin altitudes, as it is in unpressurized aircraft flying higher than 3,000 $\mathrm{m}$ [2].

In 1988, COTTRELL [4] reported in-flight cabin pressure measurements relative to altitude on 204 regularly scheduled commercial aircraft flights. He showed a median pressure exposure for all flights equivalent to an altitude of $1,894 \mathrm{~m}$, with a range from sea level to $2,717 \mathrm{~m}$, and expressed concern that higher flying newer design aircraft together with economic pressure to limit costs might lead to cabin pressures equivalent to higher altitudes. This concern has not been confirmed. The present author measured cabin pressures equivalent to altitudes ranging 580-2,460 m with a wristwatch altimeter during 28 European and trans-Atlantic flights in 1999.

At a pressure equivalent to a cabin altitude of $2,438 \mathrm{~m}$, the $P \mathrm{I}, \mathrm{O}_{2}$ is decreased by $28 \%$ from that at sea level, corresponding to an $\mathrm{FI}, \mathrm{O}_{2}$ decreased to $16 \%$. Approximately fifty years ago, DrIPPS and COMROE [5] marvelled at how little and late cardiovascular and respiratory adaptations to acutely decreased $\mathrm{P}, \mathrm{O}_{2}$ were to be observed in normal subjects. These authors showed that, when the $F \mathrm{I}_{1} \mathrm{O}_{2}$ is progressively reduced, there is hardly any increase in ventilation down to an $F \mathrm{I}, \mathrm{O}_{2}$ of $\sim 0.12$, whereas cardiac frequency starts to increase at an $F \mathrm{I}, \mathrm{O}_{2}$ of $\sim 0.16-0.18$, leading to a $15 \%$ increase at an $F \mathrm{I}_{2} \mathrm{O}_{2}$ of 0.12 [5]. In normal subjects breathing an $\mathrm{FI}, \mathrm{O}_{2}$ of 0.125 , arterial oxygen tension $\left(\mathrm{Pa}, \mathrm{O}_{2}\right)$ falls to $\sim 5.3 \mathrm{kPa}(40 \mathrm{mmHg})$, there is no significant change in ventilation and oxygen delivery to the tissues is maintained by means of an increase in cardiac output of $\sim 20 \%$ [6]. It is of interest that a $\mathrm{Pa}_{2} \mathrm{O}_{2}$ acutely brought down to $5.3 \mathrm{kPa}$ is not associated with a significant change in blood pressure $[5,6]$. It is thus evident that the lowest $P \mathrm{I}, \mathrm{O}_{2}$ permitted in the commercial aircraft cabin cannot be considered to cause cardiorespiratory stress in normal subjects at rest. At exercise, the same level of inspiratory hypoxia is associated with a decrease in maximum oxygen consumption, but is otherwise normally well tolerated [1]. During the 19th Olympic Games held in Mexico city, at an altitude of 2,240 m, the mean maximum speed during long-distance running contests was reduced by $\sim 10 \%$, in proportion to the decreased maximum oxygen consumption, but there was no report of any abnormal increase in the incidence of medical problems.

The story may, however, be different in patients with pre-existing cardiac or pulmonary diseases. These patients may be exposed to excessive in-flight hypoxaemia, as defined by a $P \mathrm{a}_{2} \mathrm{O}_{2}$ of $<7.3 \mathrm{kPa}(<55 \mathrm{mmHg})$ by the Aerospace Medical Association [7], or by a $P \mathrm{a}_{\mathrm{a}} \mathrm{O}_{2}$ of $<6.7 \mathrm{kPa}$ $(<50 \mathrm{mmHg})$ by the American Thoracic Society [8]. How predictable is in-flight hypoxaemia? It could be imagined 
that cabin pressures could be transposed into the alveolar gas equation, and in-flight $\mathrm{Pa}, \mathrm{O}_{2}$ estimated from the preflight alveolar to arterial oxygen tension gradient. However, the ventilatory as well as the cardiac responses to hypoxaemia may be reduced to variable extents, in relation to more or less compromised lung and chest wall mechanics, altered respiratory centre function due to chronic hypercapnia exposure and abnormal ventricular function. Conversely, although diffusion limitation may be unlikely, changes in $P \mathrm{I}, \mathrm{O}_{2}$, ventilation and cardiac output all are prone to affecting ventilation/perfusion $\left(V^{\prime} / Q^{\prime}\right)$ distributions and the resultant $P \mathrm{a}, \mathrm{O}_{2}$, depending on the type and extent of baseline alterations in gas exchange [9].

It is thus understandable that several groups have sought to predict in-flight $P \mathrm{a}, \mathrm{O}_{2}$ by means of preflight testing at low oxygen tensions. This has been done either by reducing the $F \mathrm{I}, \mathrm{O}_{2}$, connecting the patient to a low-oxygen circuit [10-12], or by reducing $P \mathrm{~B}$, placing the patient in a hypobaric chamber [13-15]. There is no physiological reason to believe that the cardiorespiratory effects of hypobaric or normobaric hypoxia would be different [16]. Accordingly, both types of hypoxia testing have produced comparable results [17].

DiLlard et al. [18] analysed acute normobaric or hypobaric hypoxic exposures involving 71 patients with chronic obstructive pulmonary disease (COPD) from five prior studies, and found that the change in $\mathrm{Pa}, \mathrm{O}_{2}$ per unit change in $P \mathrm{I}, \mathrm{O}_{2}$ correlated well with the pre-exposure forced expiratory volume in one second (FEV1). From these observations, the authors derived an equation for the prediction of $\mathrm{Pa}, \mathrm{O}_{2}$ at altitude $\left(\mathrm{Pa}, \mathrm{O}_{2}\right.$,alt $)$ from pre-exposure $P \mathrm{a}, \mathrm{O}_{2}\left(P \mathrm{a}, \mathrm{O}_{2}, \mathrm{~g}\right)$ and FEV1:

$$
P \mathrm{a}, \mathrm{O}_{2}, \text { alt }=P \mathrm{a}_{2} \mathrm{O}_{2}, \mathrm{~g} \mathrm{e}^{-k \mathrm{x}}
$$

where $k=0.02002-0.00976 \mathrm{FEV} 1$ (in litres) and $\mathrm{x}=$ preexposure $P \mathrm{I}, \mathrm{O}_{2}-P \mathrm{I}, \mathrm{O}_{2}$ at altitude. The authors assumed that FEV1 would be an acceptable surrogate for physiological variables that influence ventilation and $V^{\prime} / Q^{\prime}$ matching. Their equation is in agreement with the intuitive notion that patients with a preflight $P \mathrm{a}, \mathrm{O}_{2}$ of $>9.3 \mathrm{kPa}(>70$ $\mathrm{mmHg}$ ) should not be at risk of in-flight hypoxaemia [7, $10,18]$.

This opinion has been recently challenged by CHRISTENSEN et al. [19]. These authors measured arterial blood gas levels at sea level, and at $P \mathrm{~B}$ equivalent to altitudes of 2,438 and $3,048 \mathrm{~m}$ in a hypobaric chamber, both at rest and during light exercise, in 15 patients with COPD and a sea-level $\mathrm{Pa}, \mathrm{O}_{2}$ of $>9.3 \mathrm{kPa}(>70 \mathrm{mmHg})$. At $2,438 \mathrm{~m}$, five of the patients had a $P \mathrm{a}, \mathrm{O}_{2}$ of $<6.7 \mathrm{kPa}(<50 \mathrm{mmHg})$, and this hypoxaemia was aggravated during mild exercise at a level corresponding to a quiet in-flight walk. It is of interest that the preflight aerobic capacity of the COPD patients was well correlated to $\mathrm{Pa}_{\mathrm{a}} \mathrm{O}_{2}$ at pressures equivalent to $2,438 \mathrm{~m}$. All of the patients with a preflight aerobic capacity of $>12.1 \mathrm{~mL} \cdot \mathrm{min}^{-1} \cdot \mathrm{kg}^{-1}$ maintained an in-flight $P \mathrm{a}, \mathrm{O}_{2}$ of $>6.7 \mathrm{kPa}$ at pressures equivalent to $2,438 \mathrm{~m}$. Thus simple noninvasive exercise testing might perhaps suffice for the prediction of good tolerance to in-flight hypobaric hypoxia in COPD patients. Until now, exercise testing has not been included in guidelines for the preflight medical screening of patients [7, 8, 20].

In this issue of the European Respiratory Journal, RoBSON et al. [21] report their experience with hypoxia inhalation testing and an interpretational algorithm for the identification of patients at risk of respiratory distress during commercial air travel. These authors studied 28 patients with respiratory disease. Four of them, with baseline oxygen saturation measured by pulse oximetry $\left(\mathrm{S}_{\mathrm{a}}, \mathrm{O}_{2}\right)$ of $<90 \%$, were considered unfit for air travel. The rest were submitted to hypoxic breathing with an $F \mathrm{I}, \mathrm{O}_{2}$ of 0.15 , and their arterial blood gas levels were measured when the $\mathrm{Sa}_{2} \mathrm{O}_{2}$ decreased to $<90 \%$. Two patients showed a $\mathrm{Pa}, \mathrm{O}_{2}$ of $<6.7 \mathrm{kPa}(<50 \mathrm{mmHg})$ during the hypoxia test (5.3 and $6.0 \mathrm{kPa}$ (40 and $45 \mathrm{mmHg}$ ), respectively), which was corrected by supplemental oxygen. In-flight supplemental oxygen was prescribed for these two patients. The patients allowed to fly, and also one of the patients who flew against medical advice without supplemental oxygen, did not report any in-flight problems.

What is the clinical relevance of preflight hypoxia testing? Preflight normobaric or hypobaric hypoxia testing has not been associated with any reported symptomatic intolerance, even in those patients whose $\mathrm{Pa}, \mathrm{O}_{2}$ acutely decreased to $<6.7 \mathrm{kPa}(<50 \mathrm{mmHg})[10-15,17,19,21,22]$. In a study performed under more realistic conditions, ScHWARZ et al. [23], measured arterial blood gas levels in 13 patients with COPD during flights in unpressurized aeroplanes at altitudes of 1,650 and 2,250 m. None of the patients reported any symptoms, in spite of rather spectacular decreases in $\mathrm{Pa}_{\mathrm{a}} \mathrm{O}_{2}$, from a mean preflight value of $9.0 \mathrm{kPa}$ $(68 \mathrm{mmHg})$ (range $7.3-10.5 \mathrm{kPa}(55-79 \mathrm{mmHg}))$ to 6.8 $\mathrm{kPa}(51 \mathrm{mmHg})$ (range $4.3-8.1 \mathrm{kPa}(32-61 \mathrm{mmHg}))$ at $1,650 \mathrm{~m}$ and $6.0 \mathrm{kPa}(45 \mathrm{mmHg})$ (range 3.3-7.4 $\mathrm{kPa}(25-$ $56 \mathrm{mmHg})$ ) at $2,250 \mathrm{~m} \mathrm{[23].} \mathrm{In} \mathrm{an} \mathrm{invasive} \mathrm{study} \mathrm{on} \mathrm{the}$ variability of pulmonary vasoreactivity to hypoxia, WEITZENBLUM et al. [24],observed the effects of low oxygen levels in 28 patients with COPD. $\mathrm{Pa}_{\mathrm{a}} \mathrm{O}_{2}$ decreased from $8.0 \pm 0.80 \mathrm{kPa}(60 \pm 6 \mathrm{mmHg})($ mean $\pm \mathrm{SD})$ at baseline, to $5.7 \pm 0.93 \mathrm{kPa}(43 \pm 7 \mathrm{mmHg})$ at an $F \mathrm{I}, \mathrm{O}_{2}$ of 0.15 and $5.1 \pm 0.67 \mathrm{kPa}(38 \pm 5 \mathrm{mmHg})$ at an $F \mathrm{I}_{1} \mathrm{O}_{2}$ of 0.13 . Again, these impressive decreases in $\mathrm{Pa}_{\mathrm{a}} \mathrm{O}_{2}$ were well tolerated. It has long been known that COPD patients may experience transient episodes of severe hypoxaemia, with $\mathrm{Pa}, \mathrm{O}_{2}$ as low as $3.3-4.0 \mathrm{kPa}(25-30 \mathrm{mmHg})$ without immediate harm [25]. Dangerous levels of hypoxaemia have never been defined. Severe acute hypoxaemia carries risks of cerebral dysfunction, myocardial ischaemia and lung oedema, but, until now, there has been no means of determining the $P_{a}, \mathrm{O}_{2}$ below which a patient would be in danger, especially in cases of pre-existent chronic hypoxaemia.

Preflight hypoxia testing is cumbersome, expensive, time consuming and not generally available. The opinions of respiratory physicians regarding assessment methods and criteria for recommending in-flight oxygen seem to vary widely [26]. Guidelines produced by the Aerospace Medical Association [7], the American Thoracic Society [8] and the European Respiratory Society [20] describe or mention predictive equations or preflight hypoxia testing, but do not recommend their routine clinical use. In the meantime, the incidence of significant in-flight respiratory problems seems to be extremely low, in the range of one respiratory incident resulting in flight diversion per 5-10 million passengers [26, 27].

When, then, is it necessary to prescribe in-flight supplemental oxygen? It should certainly be prescribed to the pulmonary patient who already receives continuous or intermittent oxygen at home. Supplemental oxygen may also 
be considered in the hypoxaemic patient with a markedly decreased FEV1. In-flight oxygen is not indicated for cardiac patients, who most generally tolerate altitude exposure very well [28]. An exception may be the patient with pulmonary hypertension, potentially aggravated with mild degrees of additional hypoxic pulmonary vasoconstriction. If in doubt, it is important to note that in-flight oxygen is probably less expensive than preflight hypoxia testing.

After more than a quarter of a century of preflight hypoxia testing, it is now up to its proponents to design a clinical study showing that this practice is clinically relevant and cost-effective.

\section{References}

1. Ward MP, Milledge JS, West JB. High altitude medicine and physiology. 2nd Edn. London, Chapman \& Hall Medical, 1995.

2. Code of Federal Aviation Regulations. Title 14. Vol. 1. Parts 25 and 121. Washington DC, WA, US Government Printing Office, 1995.

3. Ernsting J. Prevention of hypoxemia - acceptable compromises. Aviat Space Environ Med 1978; 49: 495-502.

4. Cottrell JJ. Altitude exposures during aircraft flight. Flying higher. Chest 1988; 92: 81-84.

5. Dripps RD, Comroe JH Jr. The effect of the inhalation of high and low oxygen concentrations on respiration, pulse rate, ballistocardiogram and arterial oxygen saturation (oximeter) of normal individuals. Am J Physiol 1947; 149: 277-284.

6. Mélot C, Naeije R, Hallemans R, Lejeune P, Mols P. Hypoxic pulmonary vasoconstriction and pulmonary gas exchange in normal man. Respir Physiol 1987; 68: 11-27.

7. Aerospace Medical Association, Air transport medicine committee. Medical guidelines for air travel. Aviat Space Environ Med 1996; 67: B1-B6.

8. Anonymous. Standards for the diagnosis and care of patients with chronic obstructive pulmonary disease. $\mathrm{Am} \mathrm{J}$ Respir Crit Care Med 1995; 152: S77-S121.

9. West JB. Ventilation-perfusion relationships. Am Rev Respir Dis 1977; 116: 919-943.

10. Gong H, Tashkin DP, Lee EY, et al. Hypoxia-altitude simulation test. Evaluation of patients with chronic airway obstruction. Am Rev Respir Dis 1984; 130: 980-986.

11. Oades PJ, Buchdahl RM, Bush A. Prediction of hypoxaemia at high altitude in children with cystic fibrosis. $B M J$ 1994; 308: 15-18.

12. Cramer D, Ward S, Geddes D. Assessment of oxygen supplementation during air travel. Thorax 1996; 51: 202203.

13. Dillard TA, Berg BW, Rajagopal KR, et al. Hypoxemia during air travel in patients with chronic obstructive pulmonary disease. Ann Intern Med 1989; 111: 362-367.

14. Berg BW, Dillard TA, Derderian SS, et al. Hemodynamic effects of altitude exposure and oxygen administration in chronic obstructive pulmonary disease. JAMA 1993; 94: 407-412.

15. Dillard TA, Rajagopal KR, Slivka WA, et al. Lung function during moderate hypoxia in normal subjects and in patients with chronic obstructive pulmonary disease. $A v$ iat Space Environ Med 1998; 69: 979-985.

16. Hammond MD, Gale GE, Kapitan KS, et al. Pulmonary gas exchange in humans during normobaric hypoxic exercise. J Appl Physiol 1986; 61: 1749-1757.

17. Dillard TA, Moores LK, Bilello KL, Phillips YY. The preflight evaluation. A comparison of the hypoxia inhalation test with hypobaric exposure. Chest 1995; 107: 352-357.

18. Dillard TA, Rosenberg AP, Berg BW. Hypoxemia during altitude exposure. A meta-analysis of chronic obstructive pulmonary disease. Chest 1993; 103: 422-425.

19. Christensen CC, Ryg M, Refvem OK, Skjonsberg OH. Development of severe hypoxemia in chronic obstructive pulmonary disease patients at 2,438 m altitude. Eur Respir $J$ 2000; 15: 635-639.

20. Siafakas NM, Vermeire P, Pride NB, et al. Optimal assessment and management of chronic obstructive pulmonary disease (COPD). Eur Respir J 1995; 8: 1398-1420.

21. Robson AG, Hartburg TK, Innes JA. Laboratory assessment of fitness to fly in patients with lung disease: a practical approach. Eur Respir J 2000; 16: 214-219.

22. Berg B, Dillard TA, Derderian SS, Rajagopal KR. Hemodynamic effects of altitude exposure and oxygen administration in chronic obstructive pulmonary disease. Am J Med 1993; 94: 407-412.

23. Schwarz JS, Bencowitz HZ, Moser KM. Air travel hypoxemia with chronic obstructive pulmonary disease. Ann Intern Med 1984; 100: 473-477.

24. Weitzenblum E, Schrijen F, Mohan-Kumar T, Colas des Francs V, Lokhart A. Variability of the pulmonary vascular response to acute hypoxia in chronic bronchitis. Chest 1988; 94: 772-778.

25. Douglas NJ, Calverley PM, Leggett RJE, Brash HM, Flenley DC, Brezinova V. Transient hypoxaemia during sleep in chronic bronchitis and emphysema. Lancet 1979; i: $1-4$.

26. Coker RK, Partridge MR. Assessing the risk of hypoxia in flight: the need for more rational guidelines. Eur Respir $J$ 2000; 15: 128-130.

27. Speizer C, Rennie CJ, Breton H. Prevalence of in-flight medical emergencies on commercial airlines. Ann Emerg Med 1989; 18: 26-29.

28. Erdman J, Sun KT, Masar P, Niederhauser H. Effects of exposure to altitude on men with coronary artery disease and impaired left ventricular function. Am $J$ Cardiol 1998; 81: 266-270. 